\title{
The Dilemma of Managing Limited Liability State-Owned Enterprises in Applying the Business Judgment Rule
}

\author{
Hasrul Benny Harahap ${ }^{1}$, Bismar Nasution ${ }^{2}$, Hikmahanto Juwana ${ }^{3}$, Mahmul Siregar ${ }^{4}$ \\ \{hbhlaw92@gmail.com¹ , bismar.nasution@gmail.com², hikmah@ui.ac.id ${ }^{3}$, mahmul@usu.ac.id $^{4}$ \} \\ Universitas Sumatera Utara, Indonesia ${ }^{1,2,4}$ \\ Universitas Indonesia, Indonesia ${ }^{3}$
}

\begin{abstract}
State-Owned Enterprises (SOEs) should contribute to the national economy. Using the structure of a limited liability company as the basis for their management, limited liability SOEs place the board of directors as company managers responsible for the interests and objectives of the enterprise. As business entities, limited liability SOEs utilize the state financial system to ensure that the public aspect remains inherent in their management. This paper aims at analyzing the position of the board of directors based on the Business Judgment Rule in managing limited liability SOEs. This research uses a normative juridical method supported by library data. It aims at identifying the application of the business judgment rule principle by the limited liability SOEs board of directors. The results show that the structure of a limited liability company as the basis of the management protects directors based on the Business Judgment Rule. However, based on the state financial regulations, limited liability SOEs funds are considered part of state funds. Therefore, the losses of limited liability SOEs are considered state losses, which causes ambiguity in applying the business judgment rule in managing limited liability SOEs. Based on the principles of state funds, law enforcement officials hold the board of directors accountable as the organ that controls the company. Meanwhile, the limited liability company mechanism enables the state as a shareholder to sue the board of directors from both civil and criminal sides if proven to have made a business decision that exceeds the limits of its authority.
\end{abstract}

Keywords: Limited Liability SOEs, State Finance, Business Judgment Rule

\section{Introduction}

The political-economic system of a country shows the management of its state companies on a global stage. The current Indonesian economic system indicates the involvement of the state. We can see in the direction of SOEs, which aim to increase public welfare. In Indonesia, SOEs play two prominent roles: a state company seeking profits to increase foreign exchange reserves and as a tool for the government to provide services to the community to achieve the state's task of realizing the prosperity and welfare of its people [1]. Therefore, SOEs are classified into two types, namely public and limited liability companies.

Limited liability SOEs are subject to all the provisions and principles that apply to limited liability companies as stipulated in the Limited Liability Company Law (Law No. 40 of 2007) ${ }^{1}$.

${ }^{1}$ See Article 11 of Law Number 19 of 2003 concerning SOEs. 
In addition to being subject to SOE Law (Law No. 19 of 2003), the management of limited liability SOEs must also refer to the Limited Liability Company Law.

As the organ of management, the board of directors is fully responsible for ensuring SOEs achieve their interests and goals and represent SOEs inside and outside the court ${ }^{2}$. This forms an interdependent relationship, where the actions and activities of the company depend on the board as the organ entrusted with the management. On the other hand, the company's existence is the reason for the existence of the board; without a company, there would never be a board of directors [2].

Limited liability SOEs were formed to maximize profits. However, the risk is always involved in efforts to gain profits. Business objectives are synonymous with taking risks, and the board of directors is responsible for managing that risk, as the board's function is to make decisions for the company [3]. However, as long as the board carries out the management in good faith, within limits, and according to the provisions that have been previously determined, it is always protected by the Business Judgment Rule [4].

As a business entity whose capital comes from restricted state assets, the assets of limited liability SOEs are considered part of state assets. Therefore, the losses of limited liability SOEs are considered state losses. This view has led to various public debates, considering that SOEs are private entities with a public dimension. Mixing the two without clear boundaries has created a dilemma for SOEs in carrying out their business activities. The principles of corporate governance are confronted with state financial mechanisms with contradictory paradigms.

\section{Management of Limited Liability SOEs}

\subsection{Position of SOEs in the Indonesian Economy}

Indonesia expects SOEs to be one of the main drivers of the national economy, making them an essential pillar of development. They are expected to provide services and fulfill the needs and interests of the people at large and be the most significant contributor to the national economy. Various sectors that SOEs handle have played an important role in realizing these goals. As SOEs are a crucial part of the nation, it is appropriate that they are seen as pillars of the nation's economy.

SOEs are a source of national income, possess many assets from businesses that vary in scale and type, and are in charge of operational areas spread across almost all parts of Indonesia. As business entities, SOEs are not solely focused on profits but also prioritize public interest through relevant projects.

SOEs currently still play a crucial role in the national economy, significantly developing sectors not yet developed and sought after by private companies. As the government appoints SOEs to carry out pioneering projects, they are considered agents of development with all their strengths and weaknesses and the various controversies that accompany them [5].

Realizing the state's desire to make SOEs the pillars of the national economy requires concepts, thoughts, and extra work. The constitution has mandated the state to exercise a "monopoly" over important production branches and "control" many people's lives. SOEs have been successfully formed, but the results are below expectations. Professional management of state companies is a challenge; as business entities, SOEs are considered part of state finances, impacting its management system.

${ }^{2}$ See Article 5 of Law Number 19 of 2003 concerning SOEs. 
On one occasion, Mohammad Hatta explained that "controlled by the state" does not necessarily mean the state itself becomes an entrepreneur, merchant, or dealer. It is more accurate to say that the state's power lies in its authority to create regulations to strengthen the economy and prohibit the "exploitation" of the poor by the rich [6]. Mohammad Hatta wishes for a legal institution and norm that can competently manage SOEs to ensure that, as business entities, they can fully contribute to the national economy.

The norms governing life in organizations and society are only partially reflected in traditional sources of formal law such as laws and case decisions. There is an inevitable discrepancy between official law and actual practices. Therefore, rules should refer to existing procedures and a combination of official law and societal values, perceptions, and strategies that form hybrid laws [7].

Limited liability SOEs are treated as limited liability companies. Therefore, the management is handled by the board of directors as the party responsible for achieving the interests and goals of the company. The Limited Liability Company Law protects the board in making business decisions. However, this only applies to decisions taken to achieve company goals and fulfill the stipulated conditions. The protection ensures Limited liability SOEs as business entities can freely carry out their business activities as a form of support from the state in realizing public welfare through the development of the national economy.

\subsection{Application of the Business Judgment Rule in Corporate Governance}

Law No. 40 of 2007 regarding Limited Liability Companies has set clear standards on the accountability of the board of directors. The provisions of Article 97 Paragraph (5) of Limited Liability Company Law state that a director is free from responsibility for company losses if proven that 1) The losses arising are not due to the fault or negligence of the director; 2) The director manages the company in good faith and a prudent manner; 3) Management is carried out for the interests and objectives of the company; 4) The director does not show a conflict of interest; and 5) The director has taken steps to prevent losses. This law is crucial to ensure that directors can make business decisions. If not, it will contradict their position as risk-takers, thus indirectly stopping the company's continuous improvement. Therefore, the inclusion of the business judgment rule in the Limited Liability Company Law dramatically supports the development of the business climate in Indonesia [8].

In general, the above provisions are the principles of the Business Judgment Rule commonly found in common law countries, albeit with a slight difference. The principles of the Business Judgment Rule only apply to business decisions. However, in the Limited Liability Company Law, this principle applies to "corporate management" which is a broader aspect compared to business decisions. This means that directors can be freed from their responsibilities not only in terms of business decisions but also in the management of the company if the five elements mentioned above are proven [8].

The Business Judgment Rule experienced its development as jurisprudence in American Common Law since the decision of the Louisiana Supreme Court regarding the case of Percy V Millaudon in 1829. It is one of the most popular theories to protect directors who act in goodwill. The main aim of this theory is to achieve justice, especially in the business decisions of directors of a limited liability company [9]. According to the Business Judgement Rule, a business judgment is considered in line with the duty of care if the decision-maker possesses information about the problem and believes that the data is correct, does not have a conflict of interest, decides in good faith, and has a rational basis for believing that the decisions taken will produce the best results for the company [10]. 
America has undergone enormous changes not only in the fields of technology, economy, and culture but also in its concept of development and legal principles. Its legal scenario has been integrated with individual freedom, prevention of abuse of power, and a unique constitution [11]. The principles put forward in the Limited Liability Company Law have provided a more stable and definite business atmosphere, as directors are protected in making business decisions as long as these decisions are made to achieve company goals and follow the company's rules and regulations.

In law, the Business Judgment Rule is defined as the specific condition after a reasonable examination in which a director shows no conflict of interest, carries out actions in good faith, is honest, and rationally believes that the activities are carried out solely for the benefit of the company [12]. The Business Judgment Rule shows that directors are given substantial authority but are not allowed to place their interests above the interests of the shareholders. In other words, directors are given carte blanche to make decisions that might turn out badly but not acted out of personal interest. This balance is reflected in the various prerequisites set by the court before directors can utilize the rule [12].

\section{Limited Liability SOEs as Private Entities with a Public Dimension}

As privately managed business entities, certain conditions in which the management of limited liability SOEs are open to the public. All or most of the capital of SOEs are owned by the state through direct participation from restricted state assets ${ }^{3}$. Therefore, they are part of the state financial system and their losses are considered state losses. As business entities, SOEs are expected to contribute to the national economy and provide benefits for the community. This situation requires certainty and courage from the board of directors in carrying out business actions, as there are always risks involved in every profit-gaining effort.

Business risk cannot always be measured mathematically and is not solely based on both qualitative and quantitative information. Experienced entrepreneurs also use their instincts or hindsight to understand the size of risk. Business decisions often involve touches and gut feelings that cannot be verified by systematic analysis and are often intangible or not easy to understand. They are instincts, visions, or estimates of the state of market competition, cost structures, and the direction of industrial and economic growth. Business decisions are matters of instincts and gut feelings that cannot be systematically analyzed [13]. Directors of SOEs are not exempt from these statements; they also base their business decisions on instinct, personal touches, and gut feeling.

The dilemma regarding the accountability of SOE directors occurs due to the existence of several related laws and regulations, including Law No. 17 of 2003 concerning State Finance, Law No. 19 of 2003 concerning State-Owned Enterprises, Law No. 1 of 2004 concerning State Treasury, as well as Law No. 20 of 2001 concerning Amendments to Law No. 31 of 1999 concerning Corruption. The dilemma stems from the capital of SOEs being part of state finances, which implies that SOE losses are also state losses ${ }^{4}$.

Law enforcement and financial officers, including the Attorney General's Office, Police, Corruption Eradication Commission, and Audit Board of Indonesia, have referred to several of these laws as a package of regulations that justify SOE finances being state finances. As this

\footnotetext{
${ }^{3}$ See Article 1 point 1 of Law Number 19 of 2003 concerning SOEs.

${ }^{4}$ See the Jakarta Selatan District Court Decision in the case of the former managing director of Bank Mandiri, ECW Neloe.
} 
implies that SOE losses can potentially harm the state, the board of directors is held accountable as they are responsible for its management. Since 2014, Corruption Eradication Commission has handled several corruption cases in the limited liability SOEs, which are considered state losses, as shown in Table 1 [14].

Table1. Corruption Cases in Limited Liability SOEs

\begin{tabular}{clc}
\hline No. & \multicolumn{1}{c}{ Name of SOE } & Position of the Defendant in SOE \\
\hline 1. & PT PAL Indonesia & President Director and Finance Director \\
2. & PT Jasindo & President Director \\
3. & PT Krakatau Steel & Technology and Production Director \\
4. & PT PLN & President Director \\
5. & PT Angkasa Pura & Finance Director \\
6. & Perum Perindo & President Director \\
7. & Perum Jasa Tirta II & President Director \\
8. & PT Perkebunan Nusantara Holding & President Director \\
\hline
\end{tabular}

Differing interpretations of various state financial regulations create legal uncertainty that hinders the duties of SOE directors in carrying out their business activities, as they can be accused of corruption based on causing state losses. If SOE funds are not considered state funds, then losses only affect the company itself as a legal entity. Failures can harm shareholders; the state as shareholders can sue for these losses as stipulated in the Limited Liability Company Law.

Article 61 Paragraph (1) of Law No. 40 of 2007 concerning Limited Liability Companies states that every shareholder has the right to file a lawsuit against the company to the district court if they experience losses due to the actions of the company which are considered unjust and illogical as a result of the decisions of the General Meeting of Shareholders, Directors, and/or the Board of Commissioners. Article 97 Paragraph (6) of Law No. 40 of 2007 concerning Limited Liability Companies confirms that on behalf of the company, shareholders who possess at least $10 \%$ of the total shares with voting rights can file a lawsuit through the district court against members of the board who are responsible for the losses of the company.

Based on these laws, the state as the shareholder of limited liability SOEs has the right to sue the directors if they are proven to make decisions that are detrimental to the company, let alone if the decision exceeds the authority given to them. If there are illegal actions involved, shareholders can report them to investigators. This provision has been systemized in the Limited Liability Company Law and is referred to in managing limited liability SOEs. The internal mechanisms of limited liability companies provide room for the supervision of the board of directors in managing the company.

As a business entity, it is considered very naive to uphold company activities to the provisions of the state administration. Since its establishment, limited liability SOEs are considered private entities expected to benefit from its business activities. Since their capital originates from restricted state assets, the board of directors must ensure that this is returned in the form of profits and community benefits. This is not an easy task to do, as they are the first government institutions that utilize state funds required to return their capital in the form of profits. If limited liability SOEs are to be equalized with other government institutions, they should not be managed using the Limited Liability Company mechanism.

The Business Judgment Rule is internalized in the corporate regulations and provides room for directors to have the freedom to make decisions and optimize the company following the company's goals and objectives. In addition, this principle also provides flexibility for the 
directors to carry out their executive functions and ensure that the company will run following its regulations to achieve its goals. As private entities with a public dimension, however, the position of a limited liability SOE itself can obscure the application of this principle. Law enforcement and financial officials may have different perceptions due to the capital of SOEs originating from state funds. Therefore, company regulations cannot be used entirely as a reference in managing limited liability SOEs.

Limited liability SOEs are considered unique in their position as organizations. On the one hand, they are demanded to carry out government policies and programs as development agents. On the other hand, they must continue to function as commercial business units operating based on sound business principles. In some cases, these two functions are ambivalent and often not compatible with each other. There is a possibility of conflicting perceptions within SOEs' management, which can cause difficulty in determining strategic and operational steps [15]. Although a limited liability SOE has a public dimension, it must be managed like a private entity to get a good business format and to maximize profits as the goal of its establishment.

In managing limited liability SOEs, policies should provide certainty in conducting business. Law will play a role in economic development if it can create three qualities: predictability, stability, and fairness. Predictability means that the law provides certainty for an action taken. Stability means that the law can accommodate competing interests in society. The law must be able to create fairness, namely justice. If there is no standard of what is fair and what is right, then, in the long run, the law can lose legitimacy [16].

\section{Conclusion}

The establishment of limited liability SOEs is expected to support the realization of the national economy as an essential pillar of development. Their existence can hopefully improve public welfare. In addition to being bound by SOE Law, the management of limited liability SOEs is also based on the Limited Liability Company Law. The Business Judgment Rule is adopted in the Limited Liability Company Law to protect directors in making business decisions based on fiduciary duty.

SOE funds are considered state funds; this is an inherent principle in state financial regulations. Therefore, the losses of SOEs due to business decisions made by the board of directors are considered state losses. As the directors are responsible for managing limited liability SOEs, they are held accountable by law enforcement officials who refer to the principle as mentioned earlier. This situation causes ambiguity as the Business Judgment Rule protects the board. At the same time, the state as a shareholder can still exercise its right to sue the directors if they exceed their authority in making business decisions in both civil and criminal aspects.

\section{Acknowledgment}

This research was completed with the participation and support of the supervisor and students of the Doctor of Law Science Program, Universitas Sumatera Utara. 


\section{References}

[1] Z. Muttaqin, "Tinjuan Yuridis Mengenai Pengenaan Pajak terhadap BUMN," Universitas Padjadjaran, 1992.

[2] F. B. G. Tumbuan, "Tanggung Jawab Direksi dan Komisaris Serta Kedudukan RUPS Perseroan Terbatas Menurut Undang-Undang Nomor 1 Tahun 1995," Makal. Kuliah S2 Fak. Huk. Univ. Indones. Tahun Ajaran, vol. 2002, 2001.

[3] J. M. Burns, Leadership. New York: Harper \& Row, 2010.

[4] G. Widjaja, "Risiko Hukum Sebagai Direksi," in Komisaris dan Pemilik PT, Jakarta: Forum Sahabat, 2008.

[5] M. Yasin, M. K. Roziqin, T. Santosa, and Y. S. Al-Hadi, Membangun BUMN Berbudaya. Booknesia, 2012.

[6] M. Hatta, Cita-Cita Koperasi dalam Pasal 33 UUD 1945, Sistem Eko. Jakarta, 1987.

[7] W. Menski, "Perbandingan hukum dalam konteks global sistem Eropa, Asia dan Afrika." Bandung: Nusa Media, 2016.

[8] B. Nasution, "Memaknai Kebijakan dalam Perspektif Hukum Ekonomi," J. Huk. Samudra Keadilan, vol. 10, no. 1, pp. 1-10, 2015.

[9] D. J. Block, N. R. Barton, and S. A. Radin, The Business Judgment Rule Fiduciary Duties of Corporate Directors. Prentice Hall Law \& Business, 1990.

[10] D. F. Vagts, Basic corporation law: materials, cases, text, vol. 1. Foundation Press, 1989.

[11] P. De Cruz, "Perbandingan Sistem Hukum, Common Law, Civil Law dan Socialist Law," Bandung. Nusa Media, 2010.

[12] S. M. Bainbridge, Corporation law and economics. Foundation Press, 2002.

[13] D. M. Brandson, "The Rule that isn't a Rule: The Bussiness Judgment Rule," Valparaiso Univ. Law Rev., vol. 36, 2002.

[14] A. Umah, "KPK \& Sederet Bos BUMN yang Diciduk di Era Rini Soemarno," CNBC Indonesia, 2019. [Online]. Available: https://www.cnbcindonesia.com/market/20191007094015-17104846/kpk-sederet-bos-bumn-yang-diciduk-di-era-rini-soemarno.

[15] D. S. Priambodo, Perjalanan panjang dan berliku: refleksi BUMN, 1993-2003: sebuah catatan tentang peristiwa, pandangan, dan renungan dalam satu dasawarsa. Media Pressindo, 2004.

[16] E. Rajagukguk, "Perlunya Judicial Review UU Keuangan Negara dan Pembaharuan UU Anti Korupsi." 2011. 